\title{
Karakter dan Akhlak Pemimpin dalam Perspektif Islam
}

\author{
Siti Fatimah Siregar, Yudistira Fuady, Muhammad Fadli, Afif Al-Bukhori, \\ Putri Nurhayati Lubis, Saidatun Nisa Nasution, Riki Wahyudi, \\ Suryadi Matanari, Muhammad Junaidi \& Ira Suryani*
}

Program Magister Pendidikan Agama Islam Fakultas Ilmu Tarbiyah dan Keguruan Universitas Islam Negeri Sumatera Utara, Indonesia

E-mail: irasuryani@uinsu.ac.id

\section{Abstrak}

Artikel ini membahas mengenai pentingnya faktor karakter dan akhlak dalam kepemimpinan dari perspektif agama Islam. Kepemimpinan yang ideal berkaitan dengan kemajuan suatu peradaban dan suatu bangsa. Islam dan penganutnya menghendaki sosok pemimpin yang memiliki karakter yang baik dan akhlak yang mulia. Sumber rujukan menjadi seorang pemimpin bagi umat Islam berasal dari AlQuran dan Hadits, mencontoh kepribadian Rasulullah SAW dan para Khulafaur Rasyidin. Dalam konteks bernegara, rujukan tersebut dilandasi pula dengan aturan dan ketentuan hukum yang berlaku di Indonesia.

Kata Kunci: Karakter, Akhlak, Kepemimpinan Islam

\begin{abstract}
This article discusses the importance of character and moral factors in leadership from the perspective of Islam. Ideal leadership is related to the progress of a civilization and a nation. Islam and its followers want a leader who has good character and noble character. The source of the reference to being a leader for Muslims comes from the Koran and Hadith, imitating the personality of the Prophet Muhammad and the Khulafaur Rashidin. In the context of the state, the reference is also based on the rules and regulations of the law that inacted in Indonesia.

Keywords: Character, Moral, Islamic Leadership.
\end{abstract}

How to Cite: Siregar. S. F. Fuady, Y., Fadli. M. Al-Bukhori, A, Lubis, P.N. Nasution, S.N. Wahyudi, R. Matanari, S. Junaidi, M. Suryani, I. (2018). Karakter dan Akhlak Pemimpin dalam Perspektif Islam. Journal of Education, Humaniora and Social Sciences (JEHSS). 1 (2): -110-116.

\section{PENDAHULUAN}

Suatu masyarakat dan bangsa akan disebut sebagai masyarakat dan bangsa yang maju manakala memiliki peradaban yang tinggi dan akhlak yang mulia, meskipun dari segi ilmu pengetahuan dan teknologi masih sangat sederhana. Sedangkan pada masyarakat dan bangsa yang meskipun kehidupannya dijalani dengan teknologi yang modern dan canggih tapi tidak memiliki peradaban atau akhlak mulia maka masyarakat dan bangsa itu disebut sebagai masyarakat dan bangsa yang terbelakang dan tidak menggapai kemajuan. Untuk bisa mewujudkan masyarakat dan bangsa yang berakhlak mulia dengan peradaban yang tinggi diperlukan pemimpin dengan akhlak yang mulia.

Urgensi mempelajari tulisan ini adalah untuk dapat memahami bagaimana syarat-syarat menjadi seorang pemimpin, sifat-sifat yang harus dimiliki seorang pemimpin, dan karakter yang diharapkan dari seorang pemimpin dalam lingkup pemimpin formal dan nonformal baik yang bersumber dari Al-Quran dan Hadits maupun pada kepribadian diri Rasulullah SAW dan para Khulafaur Rasyidin serta aturan dan ketentuan hukum yang berlaku yang menjadi acuan landasan kriteria pemimpin di Indonesia.

Hal-hal yang akan dibahas dalam tulisan ini terdiri atas pengertian akhlak dan karakter, pengertian pemimpin, dalil-dalil berkenaan dengan kepemimpinan, dan karakter dan akhlak seorang pemimpin. 


\section{PEMBAHASAN}

\section{Akhlak, Karakter dan Pemimpin}

Menurut etimologi bahasa Arab, akhlak adalah bentuk mashdar dari kata akhlaqa, yukhliqu, ikhlaqan yang memiliki arti perangai (as-sajiyah); kelakuan, tabiat, atau watak dasar (atthabi'ah); kebiasaan atau kelaziman (al-'adat); peradaban yang baik (al-murui'ah); dan agama (ad-din). Kata khuluqu juga ada yang menyamakannya dengan kesusilaan, sopan santun, serta gambaran sifat batin dan lahiriah manusia.

Sedangkan secara terminologi ulama sepakat mengatakan bahwa akhlak adalah hal yang berhubungan dengan perilaku manusia. Namun, ada perbedaan ulama menjelaskan pengertiannya. Imam Ghazali dalam kitab Ihya'ul Ulumuddin mengatakan bahwa akhlak adalah sifat yang tertanam dalam jiwa yang menimbukan perbuatan-perbuatan dengan mudah tanpa memerlukan pemikiran dan pertimbangan. Sedangkan Muhammad Abdullah Darraz mendefinisikan akhlak sebagai sesuatu kekuatan dari dalam diri yang berkombinasi antara kecenderungan pada sisi yang baik (akhlaq al-karimah) dan sisi yang buruk (akhlaq almazmumah).

Dari pendapat-pendapat tersebut dapat dikatakan bahwa akhlak merupakan sifat yang tertanam dalam jiwa manusia yang dapat melahirkan perbuatan-perbuatan baik atau buruk secara spontan tanpa memerlukan pikiran dan dorongan dari luar. Dari situlah timbul berbagai macam perbuatan dengan cara spontan tanpa dibuat-buat dan tanpa memerlukan pikiran.

Dalam perspektif Islam, akhlak terkait erat dengan ajaran dan sumber Islam tersebut, yaitu wahyu. Sehingga sikap dan penilaian akhlak selalu dihubungkan dengan ketentuan syariah dan aturannya. Tidak bisa dikatakan sikap ini baik atau buruk, jika hanya bersandar pada pendapat seseorang ataupun kelompok. Karena bisa jadi pendapat tentang kebaikan dan keburukan sesuatu hal bisa berbeda antara dua orang ataupun dua kelompok.

Menurut Amin Abu Lawi, akhlak dalam perspektif Islam mempunyai nilai samawi yang bersumber dari Al-Quran. Menurutnya, akhlak dapat dimaknai dengan mengacu kepada hukum dan ketetapan syariah yang lima, yaitu: wajib, sunnah, mubah, makruh, dan haram, karena itulah realitas akhlak. Lebih lanjut dijelaskan bila akhlak berbasis kepada hukum yang lima, maka klasifikasinya seperti berikut ini. Akhlak wajib, seperti perilaku jujur, amanah, ikhlas, dan seterusnya; akhlak sunnah, seperti mengucapkan salam, memberi makan dan sedekah; akhlak mubah, seperti bermain dan bersenda gurau dengan teman; akhlak makruh, seperti tidak berinteraksi dengan masyarakat dan hidup menyendiri; akhlak haram seperti berzina, minum khamar, berdusta, berkhianat, mencuri, dan lain-lain.

Secara garis besar dikenal dua jenis akhlak; yaitu akhlaq al-karimah (akhlak terpuji), akhlak yang baik dan benar menurut syariat Islam, dan akhlaq al-mazmumah (akhlak tercela), akhlak yang tidak baik dan tidak benar menurut syariat Islam. Akhlak yang baik dilahirkan oleh sifat-sifat yang baik pula, demikian sebaliknya akhlak yang buruk terlahir dari sifat-sifat yang buruk. Sedangkan yang dimaksud dengan akhlaq al-mazmumah adalah perbuatan atau perkataan yang mungkar, serta sikap dan perbuatan yang tidak sesuai dengan syariat Allah, baik itu perintah ataupun larangan-Nya, dan tidak sesuai dengan akal dan fitrah yang sehat.

Dalam memaknai akhlaq al-karimah, penulis menyimpulkan bahwa akhlak tersebut merupakan sikap yang melekat pada seseorang berupa ketaatan pada aturan dan ajaran syariat Islam yang tercermin dalam berbagai amal. Adapun akhlaq al-mazmumah adalah sikap yang melekat pada diri berupa kebiasaan pelanggaran-pelanggaran kepada ketentuan dan aturan syariah.

Karakter menurut Soemarsono adalah kumpulan tata nilai yang mewujud dalam suatu sistem daya dorong (daya juang) yang melandasi pemikiran, sikap, dan perilaku yang akan ditampilkan secara mantap. Karakter merupakan aktualisasi potensi dari dalam dan internalisasi nilai-nilai moral dari luar yang menjadi bagian kepribadian seseorang. Karakter merupakan nilainilai yang terpatri dalam diri seseorang melalui pendidikan, pengalaman, percobaan, pengorbanan, dan pengaruh lingkungan, yang menjadi nilai instrinsik yang melandasi sikap dan perilaku. Karena karakter harus diwujudkan melalui nilai-nilai moral yang dipatrikan agar wwit $h$ http://mahesainstitute.web.id/ojs2/index.php/jehss 
menjadi semacam nilai instrinsik dalam diri yang akan melandasi sikap dan perilaku, tentu karakter tidak datang dengan sendirinya, melainkan harus dibentuk, ditumbuh-kembangkan, dan dibangun. Jadi, seorang yang berkarakter tidak cukup hanya sebagai seseorang yang baik saja, melainkan mampu menggunakan nilai-nilai kebaikan itu melalui suatu daya juang untuk mencapai tujuan mulia yang dicanangkan.

Sedangkan karakter menurut Stephen R. Covey adalah hasil pembiasaan dari sebuah gagasan dan perbuatan. Dalam sebuah pernyataan disebutkan, "Taburlah gagasan, tuailah perbuatan. Taburlah perbuatan, tuailah kebiasaan. Taburlah kebiasaan, tuailah karakter". Karenanya karakter terbentuk melalui perjalanan hidup seseorang. Ia dibangun oleh pengetahuan, pengalaman, serta penilaian terhadap pengalaman itu. Kepribadian dan karakter yang baik merupakan interaksi seluruh totalitas manusia. Inilah yang diistilahkan oleh $\mathrm{M}$. Quraish Shihab dengan rusyd. Ia bukan saja nalar, tetapi gabungan dari nalar, kesadaran moral, dan kesucian jiwa. Oleh karena itu, karakter seseorang yang dikenal buruk oleh lingkungannya sebenarnya bisa diubah atau diupayakan secara sungguh-sungguh untuk bisa berubah.

Dengan demikian, karakter terpuji sejatinya merupakan hasil internalisasi nilai-nilai agama dan moral pada diri seseorang yang ditandai oleh sikap dan perilaku positif. Karena itu, ia sangat terkait dengan kalbu. Bisa saja seseorang memiliki pengetahuan yang dalam tetapi tidak memiliki karakter terpuji. Sebaliknya, bisa juga seseorang amat terbatas pengetahuannya, namun karakternya amat terpuji. Memang, ilmu tidak mampu membentuk akhlak atau iman; ia hanya mampu mengukuhkannya. Kendatipun, ilmu mampu mengasuh kalbu, mengasah nalar, dan mengokohkan karakter seseorang (Lajnah Pentashihan Mushaf Al-Quran, 2012).

Pemimpin menurut etimologi ialah penunjuk jalan, pembimbing, mengetahui, mengepalai, memandu, dan melatih. Pemimpin menurut terminologi ialah keseluruhan aktivitas dan tindakan untuk mempengaruhi serta menggiatkan orang-orang dalam usaha bersama untuk mencapai tujuan. Orangnya disebut pemimpin, dalam ajaran Islam disebut imam, khalifah, wali, dan ulil amri (Abdullah, 2007). Pemimpin juga dapat diartikan orang yang melihat suatu masalah dan memperbaikinya, seandainya pun mereka tidak selalu tahu bagaimana caranya. Pemimpin juga bermakna orang atau sekelompok orang yang dipercaya dapat membawa kelompok orang tertentu mencapai tujuan, cita-cita dan kepentingan kelompok itu (Nuraida dan Rihlah Nur Aulia, 2010). Menurut Hadari Nawawi menyatakan bahwa pemimpin adalah seseorang yang mengarahkan, membimbing, mempengaruhi atau mengawasi fikiran, perasaan, atau tindakan dan tingkah laku orang lain (Gunawan, 2012). Berdasarkan dari beberapa pengertian di atas, maka yang dimaksud pemimpin adalah seseorang yang berperan untuk mempengaruhi, mengarahkan, menuntun, memandu serta menunjukkan orang-orang dalam suatu kelompok dalam mencapai tujuan yang sama.

Maka dapat disimpulkan bahwa akhlak/karakter seorang pemimpin adalah suatu adab atau kebiasaan seorang pemimpin yang dapat dicontoh oleh para pengikutnya dan dapat mempengaruhi, membimbing dan mengarahkan orang yang dipimpinnya.

Pemimpin dapat dibedakan menjadi dua bagian, yakni pemimpin formal dan pemimpin nonformal. Pemimpin formal ialah orang yang oleh organisasi tertentu ditunjuk sebagai pemimpin berdasarkan keputusan dan pengangkatan resmi untuk memangku suatu jabatan dalam struktur organisasi dengan segala hak dan kewajiban yang berkaitan dengannya untuk mencapai sasaran organisasi yang telah ditetapkan. Contohnya adalah pemimpin yang berada di lembaga eksekutif, legislatif, dan yudikatif mulai dari kepala desa hingga presiden, dan lain-lain.

Pemimpin nonformal ialah orang yang tidak mendapatkan pengangkatan formal sebagai pemimpin, namun karena memiliki sejumlah kualitas unggul, dia mencapai kedudukan sebagai orang yang mampu mempengaruhi kondisi psikis dan perilaku suatu kelompok atau masyarakat. Contohnya adalah tokoh masyarakat, pemuka agama, pemuka adat, ketua LSM, guru, pemimpin di perusahaan, dan lain-lain.

Ada beberapa dalil yang menjelasakan tentang kepemimpinan antara lain:

"Kami telah menjadikan mereka itu sebagai pemimpin-pemimpin yang memberi petunjuk dengan perintah Kami dan telah Kami wahyukan kepada, mereka mengerjakan kebajikan, 
mendirikan sembahyang, menunaikan zakat, dan hanya kepada kamilah mereka selalu menyembah." (QS. Al-Anbiya: 73)

"Hai orang-orang yang beriman, taatilah Allah dan taatilah Rasul (Nya), dan ulil amri di antara kamu. kemudian jika kamu berlainan Pendapat tentang sesuatu, Maka kembalikanlah ia kepada Allah (Al Quran) dan Rasul (sunnahnya), jika kamu benar-benar beriman kepada Allah dan hari kemudian. yang demikian itu lebih utama (bagimu) dan lebih baik akibatnya." (QS. An-Nisa': 59)

Kemudian di dalam hadits yang diriwayatkan oleh Bukhari dan Muslim sebagai berikut:

"Hadits Ibnu Umar radhiyallahu 'anhuma: Diriwayatkan dari Nabi shallahu 'alaihi wa salam. Sesungguhnya beliau telah bersabda: "Kamu semua adalah pemimpin dan akan dimintai pertanggungjawabannya. Pemerintah harus bertanggung jawab terhadap rakyatnya. Suami adalah pemimpin keluarganya dan wajib bertanggung jawab atas keluarga yang dipimpinnya. Isteri adalah pemimpin rumah tangga dari suami dan anak-anaknya, ia wajib bertanggung jawab terhadap mereka. Seorang hamba adalah penjaga harta tuannya, ia wajib bertanggung jawab atas harta yang dijaga. Ingatlah, kamu semua adalah pemimpin dan akan bertanggung jawab terhadap kepemimpinan tersebut”. (HR. Muttafaq 'Alaih dalam Muhalli, 2004).

\section{Karakter/Akhlak Seorang Pemimpin}

Kepemimpinan umat adalah amanah yang tidak dapat dilepaskan dari prinsip-prinsip akhlak. Padanya terdapat hak dan kewajiban moral yang timbal balik antara rakyat (umat) dengan pemimpin (penguasa). Faktor moral atau etika umat menentukan pembinaan kepemimpinan umat (Salam, 2000). Tugas seorang pemimpin tidaklah ringan. Tanggung jawab yang ia pikul senantiasa bernafaskan amanat. Baik amanat dari masyarakat/warga atau negara, bahkan agama. Agama Islam sangat memperhatikan masalah kepemimpinan. Menurut Islam semua pemimpin akan dimintai pertanggungjawabannya. Pemimpin keluarga bertanggung jawab atas kebahagiaan, kesejahteraan keluarganya, pemimpin negara/bangsa akan dimintai pertanggungjawabannya oleh masyarakat dan lain-lain.

Mengingat besarnya tanggung jawab pemimpin maka perlu mempunyai kepribadian, sikap, dan karakter yang sesuai dengan kepemimpinannya. Dia harus memegang teguh kedisiplinan, mempunyai kewibawaan, penuh sabar dan tawakal dalam menghadapi permasalahan, lapang dada, mau menerima kritik, berwawasan luas, bijaksana, selalu mementingkan terhadap kepentingan umum, berorientasi kemasyarakatan, bertanggung jawab, memiliki akhlakul karimah dan lain-lain (Mustofa, 2010).

Seorang pemimpin merupakan panutan dari yang dipimpinnya. Maju mundurnya suatu kelompok masyarakat banyak ketergantungannya kepada akhlak pemimpinnya. Seorang pemimpin harus ber-akhlakul karimah seperti akhlaknya Rasulullah dengan ciri-ciri yaitu: Shiddiq (jujur); Amanah (terpercaya); Tabligh (menyampaikan); Fathanah (cerdas) (Abdullah, 2007).

Contoh lain dapat kita jumpai dari kepemimpinan setelah Rasulullah SAW yaitu para sahabat sebagai pengganti beliau dengan sebutan "Khulafaur Rasyidin", keempat sahabat tersebut telah menjalankan sebuah kepemimpinan di atas jalan yang rasul tempuh dan mengamalkan wasiat-wasiat beliau.

Abu Bakar sebagai orang yang berwibawa dan tenang. Orangnya penuh ramah tamah, cinta sesama dan selalu membenarkan dan menepati pada rasul yang agung. Umar bin Khatab sebagai pemimpin yang mempunyai pendapat yang berbobot. Dia adalah orang yang terpercaya terhadap rahasia-rahasinya. Utsman sebagai pengumpul firman kitab Allah. Dia adalah seorang pemimpin yang meluruskan akidahnya. Sedangkan Ali bin Abi Thalib sebagai pemimpin yang pandai menyusun pasukan perang untuk mengalahkan orang-orang jahat. Ali adalah seorang pemimpin yang mampu sebagai pewaris ilmunya dan pemelihara janjinya. Demikian itulah sifat-sifat pribadi sahabat Rasulullah sebagai pemimpin Islam yang besar. Mereka adalah pemegang amanat yang teguh dan kuat. Mereka benar-benar memiliki kepribadian yang utuh dan akhlakul karimah yang tinggi. 
Apabila seseorang pemimpin memiliki akhlak yang buruk di mana hanya mementingkan diri pribadi, dan terkekang oleh hawa nafsu, yang terjadi adalah kehancuran. Suasana menjadi resah, kacau dan tidak menentu di dalam kepemimpinan orang tersebut, akan penuh goncangan, sabotase dan sistem keamanan kacau. Kondisi demikian dapat terjadi karena buruknya akhlak seorang pemimpin.

Akhlak pemimpin baik, sebab sifat, perilaku dan sikapnya dapat membahagiakan orang lain (umat manusia) dan menampakkan karismatiknya pada yang dipimpin, jadi dapat dikemukakan di sini, bahwa pemimpin berakhlak baik apabila memiliki kepribadian yang sesuai dengan tata aturan (ketentuan) agama, masyarakat, keluarga dan negara/bangsa (Mustofa, 2010).

Hal ini juga dapat kita lihat dari sosok seorang proklamator Indonesia yaitu Ir. Soekarno yang juga merupakan presiden pertama Indonesia. Beliau merupakan salah satu tokoh panutan dan tokoh yang berpengaruh di dunia, berintegritas tinggi, disiplin, semangat perjuangan dan memberikan peran besar dalam berkembangnya negara-negara di dunia. Ir. Soekarno memiliki energi dan daya tarik (karismatik) yang luar biasa untuk dapat mempengaruhi orang lain, maka tidaklah heran apabila memiliki pengikut atau masa yang jumlahnya besar. Beliau dapat mengkomunikasikan visi dan misi secara jelas, membangkitkan semangat bawahan untuk bekerja lebih giat. Hal ini juga dapat kita lihat dari sosok seorang Nelson Mandela yang merupakan mantan pemimpin kelompok perjuangan anti-apartheid di Afrika Selatan. Ia pernah dipenjara selama 27 tahun tetapi ia tetap teguh berjuang, tidak goyah dan bahkan ia tidak menanam dendam kepada orang-orang yang telah memenjarakannya. Nelson Mandela merupakan sosok pejuang di Afrika Selatan, di mana ia tancapkan secara teguh bahwa Afrika Selatan harus dibangun bersama, tidak hanya kulit hitam tapi juga kulit putih. Mandela juga bukan orang yang haus kekuasaan, ia sebagai pemimpin besar dan pejuang persamaan hak yang mau tampil sebagai "pemenang sejarah". Berakhirnya sistem apartheid berarti terbukanya kesempatan yang luas bagi warga kulit hitam untuk bekerja, baik sebagai buruh maupun sebagai seorang yang profesional untuk kemajuan bersama yakni tentunya tanpa membedakan hak dan kewajiban setiap orang.

Mandela sama seperti Soekarno yang memiliki energi dan daya tarik yang luar biasa. Bahkan di mata Mandela, sosok Soekarno adalah tokoh yang mampu membakar semangatnya memperjuangkan rakyat Afrika Selatan. Kedua pejuang ini benar-benar hebat, karena sama-sama pemberani dalam memperjuangkan sebuah kemerdekaan atas segala bentuk penjajahan dan penindasan. Mereka juga berkali-kali diancam akan dibunuh oleh lawan politiknya, tetapi mereka tak kendur berjuang (Syam, 2013).

Seorang pemimpin selain tersebut di atas hendaklah memenuhi syarat sebagai berikut.

a) Cakap. Cakap di sini dalam arti dapat mengatur umatnya (yang dipimpin) dan lebih mementingkan kepentingan rakyatnya di atas kepentingan pribadinya.

b) Adil. Sebagai pemimpin harus adil di dalam memimpin rakyat. Seperti Hadits Rasulullah SAW: "Makhluk yang paling dicintai Allah adalah pemimpin (imam) yang adil." (HR. Ahmad)

c) Jujur, memenuhi kewajiban, tanggung jawab, dan amanah. Dengan sifat jujur yang terhujam kuat dalam dada seorang pemimpin dapatlah dia memelihara amanah dengan baik. Nabi bersabda: "Hai Abu Dzar, kau seseorang yang lemah dan jabatan itu sebagai amanah yang pada hari kiamat akan menjadi penyesalan dan kehinaan, kecuali orang-orang yang menunaikan kewajibannya dan memenuhi tanggung jawab." (HR. Muslim)

d) Rendah hati. Seorang pemimpin tidak boleh menjadi pemimpin cabang atas saja. Tetapi di samping berpucuk ke atas, harus merakyat. Selalu melakukan integrasi dengan kaum (rakyat) yang lemah. Turun ke bawah, mendengarkan keluhan rakyat banyak dan amanah. Banyak orang yang menjadi pemimpin, kerap kali praktiknya seperti dalam peribahasa "Kalau hari sudah panas, lupa kacang akan kulitnya". Sifat sombong, congkak, tinggi hati, bukan hanya sekadar itu, kadang-kadang sampai hati pula menginjak-injak orang yang telah bekerja sama menaikkannya menjadi pemimpin.

e) Partisipasi dan kritik. Setiap pemimpin memerlukan dukungan dan partisipasi dari rakyat banyak. Bagaimanapun kemampuannya, ia tidak bisa melaksanakan tugas-tugas tanpa partisipasi dari rakyat. Kalau orang banyak tidak mau tahu terhadap segala anjuran dan 
tindakannya maka ia akan menemui kegagalan. Seseorang pemimpin harus terbuka untuk menerima kritik, asal saja kritik itu sehat, bersifat membangun. Seorang pemimpin harus mempunyai pendirian bahwa orang-orang yang berani terus-terang mengemukakan kesalahan, kelemahan dan kekurangan di hadapannya, itulah sahabat yang setia, bukan orang-orang yang hanya pandai "mengangguk anggukkan kepala" (Abdullah, 2007: 228).

f) Membela orang yang lemah, mengendalikan orang-orang yang kuat. Seorang pemimpin ha-rus memperjuangkan nasib kaum yang lemah dan tidak berdaya. Nasib mereka harus diangkat dari kemiskinan, kemelaratan, kemunduran, dan kebodohan. Orang-orang yang kuat, kaya, dan pintar harus dimanfaatkan secara proporsional untuk mewujudkan keadilan dan pemerataan.

g) Pemimpin harus amanah. Seorang pemimpin harus amanah terhadap apa yang dipercayakan kepadanya, supaya dia mempunyai pengaruh dan wibawa kepada rakyat yang dipimpinnya. Seorang pemimpin haruslah siap sedia untuk mundur apabila ia melakukan kesalahan atau penyelewengan. Seperti, seorang imam dalam shalat berjamaah yang harus mundur apabila dia "buang angin" sebab wudhunya pada waktu itu sudah batal, dia harus meninggalkan tempatnya, dan digantikan oleh imam baru yang biasanya berada pada shaf pertama dan mempunyai syarat-syarat yang diperlukan. Melaksanakan amar ma'ruf nahi munkar. Prinsip ini merupakan tugas kewajiban bagi setiap muslim dan pemimpin. Karena di tangan pemimpin terdapat kekuatan dan kekuasaan untuk mendorong manusia berbuat kebajikan dan mencegah kemungkaran.

Bentuk-bentuk kepemimpinan dalam Islam ada tiga macam, yaitu: 1) Pimpinan tradisional, pemimpin seperti ini hanya berdasarkan kepercayaan dan kebijaksanaan rakyat yang memilih secara turun-temurun; 2) Pimpinan berdasarkan pertimbangan akal (formal), berdasarkan peraturan-peraturan hukum yang disusun oleh manusia dan tunduk pada peraturan tersebut. 3) Pimpinan kharismatik yaitu pemimpin yang dicintai dan dipilih oleh rakyatnya karena ketegasannya, kemampuan melindungi rakyatnya dan seluruh kharismatik yang dimilikinya.

Untuk mengangkat seorang pemimpin, harus dipenuhi persyaratan sebagai berikut: 1) Pemimpin harus orang yang beriman, bukan sekadar Islam saja; 2) Pemimpin harus menguasai Al-Quran dan Hadits, serta berpegang kepada keduanya; 3) Pemimpin harus mampu memimpin seluruh lapisan masyarakat dari berbagai agama; 4) Pemimpin harus benar-benar bertanggung jawab (Abdullah, 2007).

Untuk menjadi seorang pemimpin menurut ketetapan MPR/XIII/1996 adalah sebagai berikut: 1) Bertakwa kepada Tuhan Yang Maha Esa; 2) Setia pada Pancasila dan Revolusi; 3) Berwibawa; 4) Jujur; 5) Cakap; 6) Ahli dalam bidangnya; 7) Adil; 8) Mendapat dukungan dari rakyat; 9) Tidak terlibat G-30 S/PKI dan berorganisasi terlarang lainnya.

Menurut konsep akhlaqul karimah, prinsipnya setiap umat perlu menghiasi diri dengan akhlak baik dan menjauhi akhlaqul mazmumah. Maka dari itu pemimpin harus mempunyai sifatsifat kepemimpinan sebagai berikut: 1) Beriman dan bertakwa. Apabila keimanan dan ketakwaan tidak ada pada seorang pemimpin maka mustahil mencapai kesuksesan di akhir kepemimpinannya; 2) Sehat jasmani dan rohani. Pemimpin harus kuat fisik dan mentalnya untuk mengemban amanah kepemimpinannya; 3) Berilmu dan berpengetahuan sesuai dalam bidang keahliannya. Nabi bersabda, "Jika segala urusan diserahkan kepada bukan ahlinya maka tunggulah kehancurannya." (HR. Al-Bukhari); 4) Berani dan bertanggung jawab. Maksudnya berani mengambil keputusan sekalipun pahit dan bertanggung jawab dari segala aspek yang dihadapi; 5) Jujur. Pemimpin yang jujur dapat melaksanakan tugasnya dan hasilnya tidak diragukan oleh yang dipimpin. Nabi bersabda: "Ahli surga ada tiga: Penguasa yang jujur (lurus) dan memperoleh taufik, orang yang berbelasa kasih dan lembut hati kepada keluarga dan kepada sesama muslim, dan orang miskin berkeluarga yang tetap menjaga kesopanan dan kehormatan diri." (HR. Muslim) (Abdullah, 2007: 230); 6) Hikmah. Pemimpin perlu memiliki hikmah sebagai alat istimewa. Hikmah sering diartikan sebagai ilmu pengetahuan yang diberikan Allah sehingga dapat bijaksana dalam tindakan; 7) Lapang dada dan menerima dengan hati yang tenang. Sifat ini 
perlu bagi seorang pemimpin sehingga seorang pemimpin tidak bersifat otokratik dan diktator; 8) Penyantun dan pengasih. Sifat ikhtiar dan rela berkorban bagi seorang pemimpin dalam melayani umatnya merupakan kewajiban. Karena kalau tidak pemimpin itu hanya akan mementingkan dirinya sendiri; 9) Tekun, ulet dan sabar. Pemimpin harus tahan uji, ulet dalam bekerja, tidak putus asa, dan sabar dalam melaksanakan tugas-tugasnya; 10) Berakhlakul karimah. Pemimpin itu harus memiliki sifat-sifat al-karimah dan menjauhi sifat al-madzmumah.

\section{SIMPULAN}

Akhlak pemimpin harus memenuhi kriteria di atas, perilaku dan sikapnya dapat bahagiakan orang lain dan menampakkan karismatiknya pada yang dipimpin. Jadi dapat dikemukakan bahwa pemimpin yang baik wajib memiliki kepribadian yang sesuai dengan tata aturan agama Islam, undang-undang, adat istiadat, masyarakat, dan bangsa. Sebagai timbal balik dari sikap pemimpin terhadap rakyat maka rakyat pun mempunyai sikap-sikap tertentu kepada pemimpin yang diajarkan oleh etika Islam. Seyogyanya rakyat selalu mendoakan pemimpinnya kepemimpinannya berhasil dan berjalan pada garis yang diridhai Allah.

\section{DAFTAR PUSTAKA}

Abdullah, M.Y. (2007). Studi Akhlak dalam Perspektif Al-Quran. Jakarta: Amzah.

Departemen Agama RI. (2010). Al-Quran dan Terjemahnya. Bandung: Diponegoro.

Gunawan, H. (2012). Pendidikan Karakter Konsep dan Implementasi. Bandung: Alfabeta.

Kartono, K. (1988). Pemimpin dan Kepemimpinan. Jakarta: Rajawali.

Lajnah Pentashihan Mushaf Al-Quran. (2012). Pendidikan, Pembangunan Karakter dan Pengembangan Sumber Daya Manusia. Jakarta: Aku Bisa.

Muhalli, A.M. \& Hasbullah, A.R.. (2004). Hadits-Hadits Muttafaq 'Alaih Bagian Munakahat dan Mu'amalat. Jakarta: Kencana.

Mustofa, A. (2010). Akhlak TaSAWuf. Bandung: Pustaka

Syafri, S. Amri, U. (2012). Pendidikan Karakter Berbasis Al-Qur'an. Jakarta: Rajawali Pers.

Nuraida \& Aulia, R.N. (2010). Pendidikan Karakter untuk Guru. Jakarta: Aulia Publishing House.

Salam, B. (2000). Etika Individual Pola Dasar Filsafat Moral. Jakarta: Rineka Cipta.

Syam, A.M. (2013). "Mendunia Ada Mandela, Juga Soekarno. Untuk Indonesia Siapa?”, diakses dari http://m.kompasiana.com/amsyam/mendunia-ada-mandela-juga-soekarno-untuk-sekarang-diindonesia-siapa-. 